\title{
Religious and spiritual motifs in the art of the patients of Nikkilä Hospital
}

\author{
DOI: https://doi.org/10.30664/ar.98057
}

(c) Attribution 4.0 International (CC BY 4.0)

$\mathrm{T}$ his article focuses on religiousness and spirituality in the art works of psychiatric patients of Nikkilä Hospital, Finland. The pictures analysed here belong to a collection held at the Helsinki City Museum and they were made during the twentieth century. The theoretical frame of the study is a cultural study of mental health. The collection is approached as presenting a specific kind of imagery which has connections not only to the personal history and diagnoses of the patients; their cultural context and hospital environment is also taken into account. The religiousness and spirituality of the Nikkilä collection are also compared with outsider art and examples of art history internationally.

\section{Introduction}

The Virgin Mary with her child, the Christ carrying the crown of thorns, angels and devils, pictures of churches, symbols of the evangelists, crosses and anchors, ships and boats, spiritual landscapes. In the collection of pictures made by the psychiatric patients of Nikkilä Hospital there are numerous motifs and symbols which can be clearly categorized as religious, but there are also works whose religiousness and spirituality can be interpreted more widely. In this article, I will analyse the pictures of the Nikkilä collection from the perspectives of religiousness and spirituality.

The Nikkilä Hospital, a mental health facility located in Sipoo, was founded in the 1910s for patients from Helsinki. The first patients entered the hospital in 1914 and the last left in 1999 when the hospital was closed. In Nikkilä the use of art practice as an element of rehabilitation was begun as early as in the 1930s, during the period of chief physician Sven Donner (1890-1970). Subsequent chief physicians of Nikkilä Johan Runeberg (1903-61), Erkki Lehtosuo (1912-97) and Oscar Parland (1912-97),

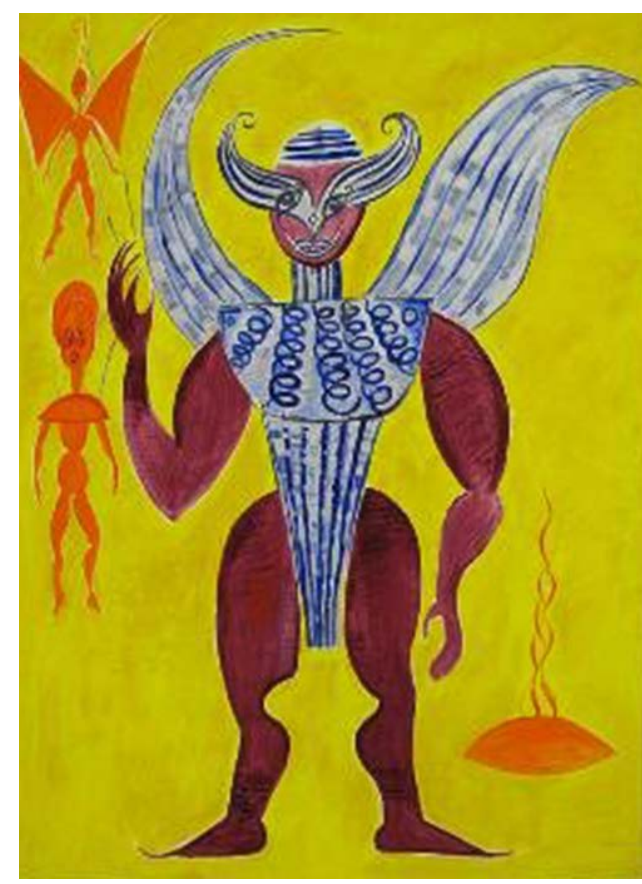

Helsinki City Museum, NSM I121 - EiNo, 1984. 
were also deeply interested in art and continued along the same lines after the war. Initially the patients were given the opportunity to draw, paint, and do pottery with the provision of a room and materials for art. The works were sometimes referred to when evaluating the effectiveness of the patients' treatment (Tikka and Tukia forthcoming; Tuovinen 2009: 8, 188, 32833). The collection of patients' works was transferred to the Helsinki City Museum in 2000 when the Nikkilä Hospital was closed. Nowadays the collection is physically in the warehouse of the Helsinki City Museum. Part of the collection has been digitized, and is available for researchers at the museum. The whole collection includes about 5,000 works - paintings, drawings and other handicrafts such as ceramics (Tuovinen and Aronsson 2018: 71). Among the 2,000 digitized works there are about 200 pictures which I found to be associated with religiousness and spirituality - about one-tenth of all of the electronically stored pictures.

The artist Rafael Wardi (b. 1928) started at Nikkilä Hospital as an art club instructor in 1959 and continued working there until 1986. His work in Nikkilä was charitable. The hospital provided equipment and space for artistic work and guided the patients into the art groups. Previously, Wardi had run an art club at Kellokoski Hospital. Wardi's motto for working with the patients was 'What can be done!' (Mitä voidaan tehdä!). The starting point was the individual with his/her personal abilities and interests. The aim was to develop the self-understanding of the patients and to give them some tools to express themselves. Pencils, crayons, finger paints, watercolours and pastels were most frequently used. Art exhibitions of the club were held annually in Nikkilä, and sometimes also outside the hospital. Sometimes the patients also visited the homes of artists (Tikka and Tukia forthcoming; Tuovinen 2009: 189-90). ${ }^{1}$

In the Nikkilä collection the earliest art works are from the 1940s, and most of the works were done between the 1960 s and 1980 s. Although it isn't possible to define the intentions behind the works, some keys to their interpretation can be found through interviews of the personnel of Nikkilä Hospital. For example, Wardi has described his experiences of the work with the patients and his working methods in interviews (e.g. Anhava 2005; Tikka and Tukia forthcoming; Tuovinen 2009). Although individual scholars have described certain aspects of the art of Finnish psychiatric patients, the subject has not yet been widely studied (e.g. Cadogan 2008; Elovirta 2005; Hämäläinen 2018; Hämäläinen forthcoming; Haveri 2010; Parland 1991; Tolvanen 2006; Tuovinen 2009; Tuovinen and Aronsson 2018). Therefore, investigations of the art of the patients from an international perspective provide important points of comparison. In international studies of the art of psychiatric patients the theme of religiousness is frequently discussed (e.g. Prinzhorn 1922/72; MacGregor 1989; Rhodes 2000; Beyme et al. 2019), but how do the religious motifs in international examples relate to the religious motifs of Finnish works?

Many things complicate the interpretation of the religious and spiritual content of the pictures. The personal histories and diagnoses of the patient artists are not known. The author's date of birth or

1 The selection of digitized pictures was made by two visual artists, Tommi Matikka and Leena Kaisa Palonen in 2020. In addition, some works have been digitized when being shown in exhibitions (Elina Kallio's email to Sari Kuuva, 2.5.2019.) 
gender is also not reported, and if there have been signatures on the pictures, they have been covered when possible. The effort to pseudonymize pictures is ethically justified when discussing the art of psychiatric patients, although some of the artists amongst them may have been individuals who would have been happy that their names were mentioned in relation to their works. Wardi mentioned in his interview that it didn't make sense that the names of the patients were never mentioned in the exhibitions (e.g. Tikka and Tukia forthcoming). In the digitized portion of the Nikkilä collection authorial codes have been applied to the artists which helps with seeing which of the works in the collection have been made by the same person. However, not all the digitized images are marked with such a code in the database, which indicates that the author's identity was not always known by the persons who catalogued the works. Sometimes, the author code ' $\mathrm{XY}$ ' has been used when the author is unknown, and other times the words 'author known' indicate that the author was a culturally well-known person. Sometimes the year the work was completed is known, but in many cases that information is also missing.

\section{Religion and mental illness}

The relationship between mental illness and religiousness has been widely discussed (e.g. Porter 1987: 82-102; Pietikäinen 2013: 23-66; Pietikäinen 2020: 65, 67-8, 85-6, 145-6, 217, 219, 231, 238-9, 261, 263). According to the historian of psychiatry Petteri Pietikäinen, between the world wars - during the first half of the twentieth century - Finnish people were clearly more religious than nowadays, and the majority of the population were members of the Lutheran or Greek Orthodox Church. Although religion has certainly brought com- fort to many patients and given meaning to their own experiences, it has also been a source of blame and shame. As stated by Pietikäinen, the Church of Finland was often disciplinary and recriminatory rather than receptive and kind, and this harsh and sometimes even narrow-minded religiosity left its mark both on healthy and mentally ill citizens. At the beginning of the twentieth century the Finnish Lutheran clergy persisted in its tendency to preach about original sin, Hell and a judgmental God, and the therapeutic turn in religion came about only after the war (Pietikäinen 2020: 145, 217; see also Kivivuori 1999: 26-30).

In many contexts mental illness has been associated with a problematic relationship with religion. Karl Johan Lind (1832-1917) and Aino Manner (18851975) were among the first Finnish patients who published autobiographical descriptions of mental illness and life in a psychiatric hospital. Kirsi Tuohela (2015), a researcher of cultural history, has analysed these texts where the theme of religiousness is strongly present. K. J. Lind was a theologian who was treated at Lapinlahti Hospital in 1872-4. Lind wrote his text entitled 'Ur en själasörjares anteckningar 1. angående sinnesjuka och deras vård' as early as 1874 , but it was not published until 1911.

Religious care was an essential part of the treatment of the patients of psychiatric hospitals in the nineteenth century, but its importance diminished as the century went on. There was a priest working in Lapinlahti Hospital, for example, in the late nineteenth century. He preached on Sundays and offered the comfort of religion through discussions with patients who needed it. However, as Thiodolf Saelan (1834-1921), chief physician of Lapinlahti Hospital, pointed out as early as the 1870 , it was common knowledge among psychiatrists that the religious reflections of some 
mentally ill people could be understood to be symptoms of an illness, and in these cases religious interaction with someone inadequately qualified could even exacerbate the situation of the patient. As a later chief physician of Lapinlahti, Kalle Achté (1928-2019) suggested, one of the diagnoses used during Lind's time was Melancolia religiosa, which is based on the idea that mental illness can be caused by excessive religious practice (Achté 1982). Many psychiatrists, thus, saw religious pastoral care only as a marginal aid - often as unnecessary and sometimes even harmful. Priests disagreed with this and understood the treatment of the deluded mind primarily to be a task of religious pastoral care. Their opinion was that the doctors, who focused on the body, did not understand spiritual contradictions well enough (Tuohela 2015: 199-200).

Lind also strongly emphasized the notion, typical for his period, that psychiatric disorders have a spiritual foundation. In his view, patients would have been better treated with the help of theology than through medicine. According to Lind, it would be particularly important to be clear about the passions that have brought patients' soul functions out of balance, but at the same time it would be essential to try to restore patients' minds and strengths in an appropriate way - through selected words from the Bible and suitable religious pictures (Lind 1982: 48-50). Lind, thus, opposed the idea that mental illness was caused by excessive religiosity and assumed that anxious people in difficulty tended to rely on religion.

Tuohela has compared Lind's memoirs from the late nineteenth century to Aino Manner's memoirs of a psychiatric hospital in the early twentieth century. She has paid attention, for example, to the differences between the two authors' conceptions of the soul. For Manner, mental illness, like physical illness, is inherited and biological in its causes and origins; not religious or spiritual. Manner also discussed the concept of the soul with the publisher of her memoirs and insisted that mental illness was a disease of the mind and not of the soul. For example, according to Manner, a soul of a religious seeker might be sick - not his/her mind. When distinguishing between mind and soul Manner thought differently than Lind, who equated mental illness with sin and believed in religious soul care. The distinction between mind and soul was not always scientifically clear in the early twentieth century either. For example, psychology, focusing on the mind, was also called the 'science of the soul' in Finland (Tuohela 2015: 221-3).

In 1894, the pastoral care of Lapinlahti hospital and general hospital of Helsinki was managed in accordance with the Imperial Proclamation and the preacher was hired on state funds. The first post for a preacher in municipal hospitals was established in 1925. However, in the hospital at Nikkilä the priests and cantors of the parish of Sipoo performed the ecclesiastical duties of the hospital on a part-time basis. Services, hours of devotion and other ecclesiastical events played an essential part in hospital life. The first hospital theologian started to work in Nikkilä in 1962 and later there were also hospital priests. Theologians of Nikkilä co-operated with psychiatrists and psychologists and sometimes the doctors encouraged their patients to speak with a theologian (Tuovinen 2009: 246-51).

\section{Religion and spirituality}

Religious art has traditionally been examined within a multidisciplinary and heterogeneous field of research called art and religion (e.g. Kokkinen 2019a: 31-2). In this article, I will discuss what religiousness 
and spirituality could mean in the context of the art of psychiatric patients (see, e.g. Kokkinen 2019a; Kokkinen and Nylund 2020; Mahlamäki and Kokkinen 2020; Viholainen et al. 2020). After discussing these concepts I will describe what kind of religious and spiritual features there are in the works of the Nikkilä collection.

The theoretical frame of my study is a cultural study of mental health (e.g. Jäntti et al. 2019: 9-45; Kinnunen 2020: 9-15). The goal is to approach the works of the patients from a different perspective than is typically done in the psychiatric, diagnostic analysis of the works of the patients. When the works of the patients are approached through the frame of a cultural study of mental health, the collection is approached as a specific kind of imagery which has connections not only to the personal history and illness of the patients, but also the surrounding cultural context and features of the hospital environment are taken into account. A cultural study of mental health can also open perspectives onto the role of art and art-making in the well-being of the patients.

In this article religiousness refers to motifs that can be identified as religious through specific symbols associated with Christian iconography or the religious imagery of other cultures. When compared to religiousness, spirituality is a more loosely defined, less dogmatic, less authoritarian and less regulated category. According to Nina Kokkinen, a scholar of religions, particularly at the turn of the nineteenth into the twentieth century, spirituallyoriented art aimed to reach and depict eternal universal truths and it tended to separate from traditional Christian art by turning towards mysticism where alternative religious movements played an important role. In this context the artists creatively combined different threads of spirituality rather than committed to individual religious or scientific dogmas (Kokkinen 2019b: 362-4, 374-5). In the context of the Nikkilä collection the works I have categorized as spiritual somehow relate to inner experiences of the patients. For example, there are works which cannot unambiguously be understood as pictures of nature as they seem to depict the life and situation of human beings through the elements of nature. These kinds of works can be understood as spiritual. In some cases when the works clearly have connections with esoteric ideas and symbols, the concept of esoteric spirituality is used (cf. e.g. Kokkinen 2019a: 22-4).

When studying the pictures, I have extensively reflected on the criteria for my analysis: on what basis I have categorized one work as religious and another as nonreligious, one as religious and another as spiritual? My interpretations are not based on knowledge of the patients' personal histories or their medical diagnoses; rather I have studied the pictures as pictures, as a part of Nikkilä Hospital's collection of the works of the patients, and even as a part of a broader category of international art by patients. I have aimed to clarify what is typical and what is atypical in the artistic expression of psychiatric patients. Therefore I have studied individual pictures in relation to other pictures - both in relation to the art of the patients and the works known from art history. From this perspective, it is not a diagnostic, but a culturally contextualizing form of interpretation.

I call my method visual analysis, with an emphasis on the study of the symbolism of the pictures. By symbolism, I mean both visual signs contained in the pictures, and the means of expression. When analysing the pictures I have drawn attention to the symbols which have been used, looked at how the symbols have combined 


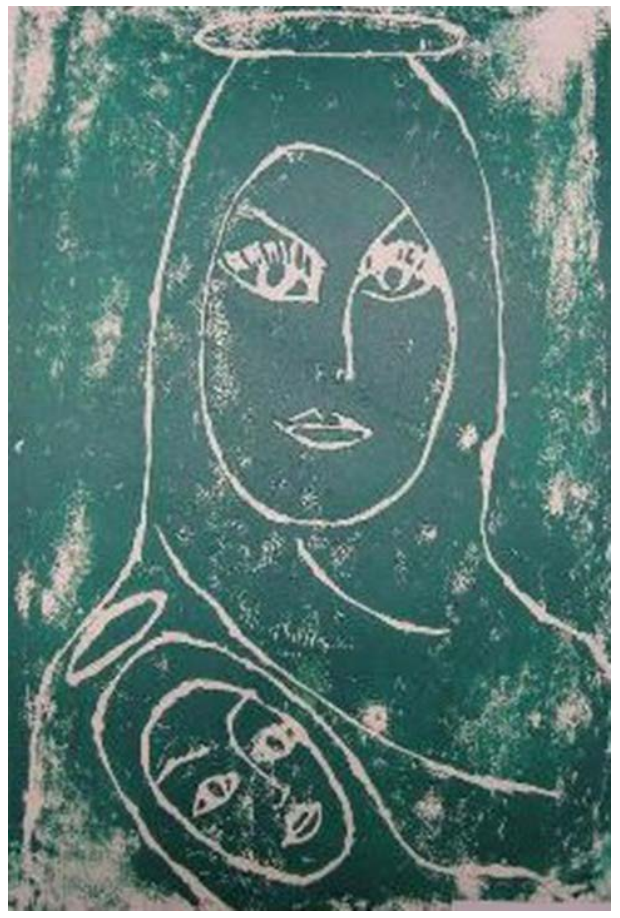

Helsinki City Museum, NSM 1121 - 3412, 1982.

with other visual elements around them, and how the use of the symbols relates to ways in which other patients or known artists use them. The patients' original ways of using symbols have also attracted the interest of many early researchers of the art of the patients of psychiatric hospitals, such as Cesare Lombroso (1835-1909), Marcel Réja, Hans Prinzhorn (1886-1933), and John MacGregor (MacGregor 1989: 99, $182,188,202)$.

When classifying the works as religious or spiritual I have remained aware that I have no access to the intentions of the authors and I cannot be sure how the patients have understood the motifs they have worked with. Ann Taves, a scholar of religion, has made a distinction between the concepts of 'religious experience' and 'experience evaluated as religious' (see Salmesvuori 2020: 176). Recent studies of religions have shown that today an increasing number of people classify themselves as spiritual rather than religious. In this context, spirituality is seen as a concept with freer boundaries than a more precisely understood religiousness. It is also important to note that there is no clear line between religiousness and spirituality, but at some point spirituality may approach, or become, a stricter, more dogmatic, more authoritarian religiosity (Moberg et al. 2015: 65-6).

\section{Religious and spiritual motifs in the works of patients of Nikkilä Hospital}

During the early twentieth century church art and altar paintings were the most frequently seen art works among most Finnish people (cf. e.g. Takanen 2020: 17-18). Therefore, it is not surprising that there are numerous pictures with biblical themes in the Nikkilä collection. For example, there are religious motifs, such as pictures of Christ, the Virgin Mary, devils and angels, and symbols of the apostles. Some of the motifs have a clear derivation in the history of art, while some of the authors have interpreted Christian motifs more freely.

\section{Religious figures: the Virgin Mary and Christ}

The motif of a mother and child can be understood as religious when the persons depicted have a halo around their heads. However, the Nikkilä collection also contains works where it is possible to see the mother and child as secular figures. Usually the Virgin Mary appears in the pictures alongside Christ. Individual pictures of her have connections with the depiction conventions of Greek Orthodox icons and one painting of the Virgin Mary in the Nikkilä collection also imitates a mosaic surface frequently utilized in ecclesiastical art.

In the pictures the Virgin Mary and her child are sometimes placed in an anonymous space, and other times they stay in a meadow or stable next to an angelic 
character, ox and donkey.

Usually the child Christ lies in the arms of his mother, but in the painting containing the Pietà motif the Virgin Mary holds an adult, wounded Christ in her arms. Internationally, many patients of psychiatric hospitals have depicted themes related to the Virgin Mary. For example, the Virgin Mary is often a key figure in the works of Peter Moog, presented in Prinzhorn's study Artistry of the Mentally Ill (Prinzhorn 1922/72: 144-58).

The roles of the figure of Christ in the works of patients are more numerous than the roles of the Virgin Mary. Although the child Christ is usually depicted with his mother, there is one work in the Nikkilä collection where the child figure with a halo is alone in a blue landscape, kneeling at the edge of the water with a white flower in the background. In other works from Nikkilä Christ has been depicted, for example, as a shepherd, knocking on the door, as arrested, in his crown of thorns, and carrying the cross. The point that there are many pictures in the Nikkilä collection of a suffering Christ with a crown of thorns on his head, as well as Christ carrying his cross, can probably be linked with sufferings experienced by the patients. Suffering and the crucified Christ is also a frequently repeating motif in the art of the patients of psychiatric hospitals internationally. Prinzhorn has presented these motifs for example, while discussing the theme of the increased significance in the works of the patients. In this context Prinzhorn describes the challenges of interpreting the symbolism in the art of the patients as follows:

Whether we are able to interpret symbols - and allegories not easily distinguishable from symbols - depends primarily on the extent to which an

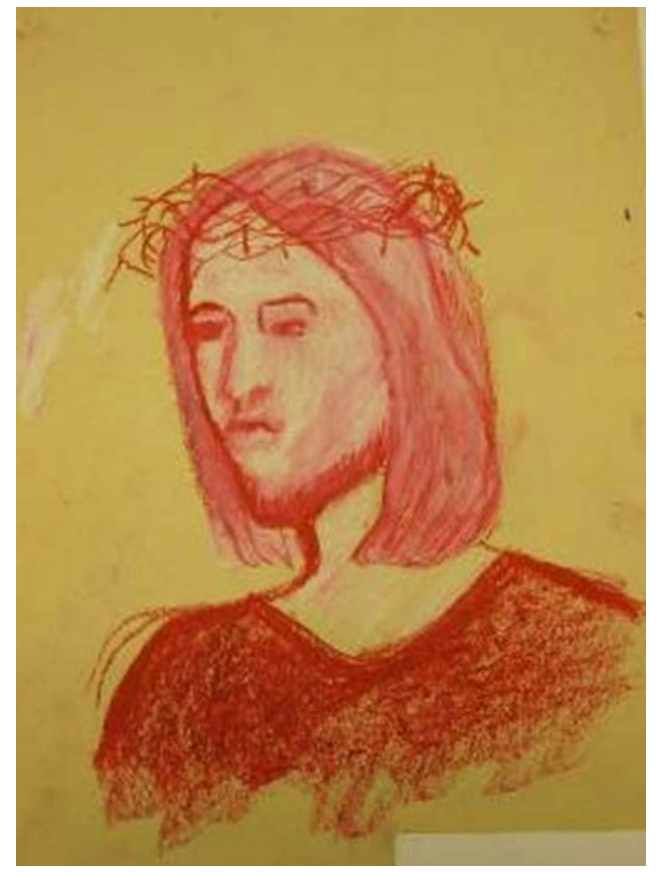

Helsinki City Museum, NSM I121 - 2721, 1976.

artist uses conventional symbols or, on the other hand, undertakes to coin new ones. We must further distinguish magic, occult meanings when they can hardly be deducted from a picture but are supplied only by verbal explanation. (Prinzhorn 1922/72: 84)

In the Nikkilä collection religious symbols are usually quite conventionally used, but there are also examples of nonconventional uses of religious symbols. However, if there are no verbal descriptions which explain the meanings of symbols it can be quite challenging, and even problematic, to define exact meanings of unconventionally used symbols in the works of the patients.

In the Nikkilä collection religious symbols are used most conventionally in the works which are copies of well-known pieces of art, such as Warner Sallman's (1892-1968) The Head of Christ (1940) and Mihály Munkácsy's (1844-1900) Christ in 


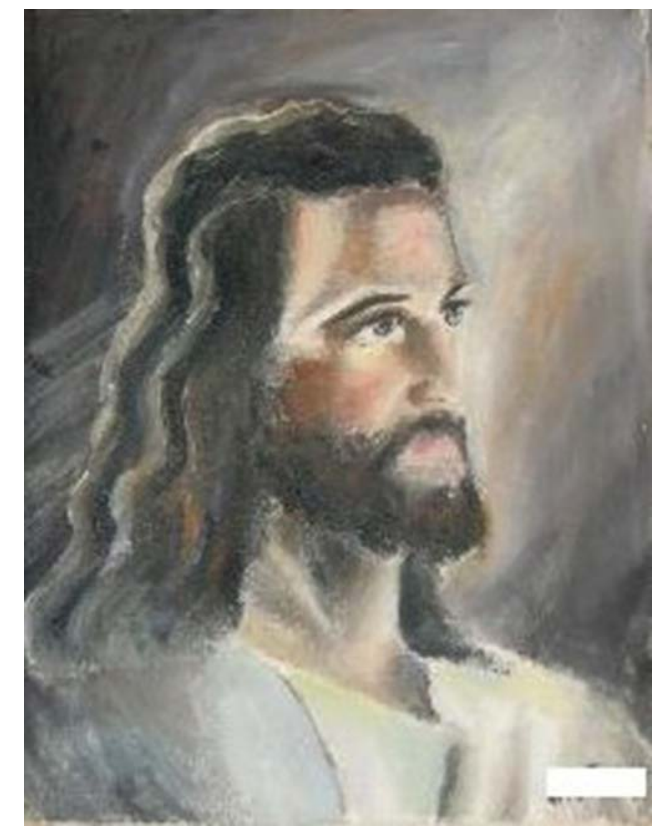

Helsinki City Museum, NSM 1121 - 974, no date.

Front of Pilate (1881) (see, e.g. Morgan 1998: 1-20). However, there are also examples in which the symbolism is more ambiguous. For example in one work, a bearded figure with a cloak seems to float in the space, surrounded by the stars, and the picture is entitled Master of the Universe. In the context of more originally treated motifs such as this it is more difficult to define whether the motif is spiritual or not, and what has been the significance of the work for the author.

There are individual works in the Nikkilä collection, in the context of which I reflected on the explanatory value of the concept of esotericism. Usually esoteric knowledge has been understood as hidden, potentially revealing, and reachable by following a certain pattern or path (Hanegraaff 2006: 336-40; Mahlamäki and Kokkinen 2020: 13-14). Some pictures and texts of the patients of psychiatric hospitals contain meanings that are not intended to be understood by outsiders. However, it is not a question of esotericism in the same way as, for example, in the context of the works of artists belonging to certain religious or spiritual communities or secret societies might be, because the meanings are not collectively shared in the case of the patients. As Colin Rhodes has pointed out, outsider artists often have a problematic relationship to religiosity which manifests as a desire to create their own universe and symbolic language (Rhodes 2004: 109).

Like esotericism, mental illness can sometimes also be associated with specific kind of knowing - knowing otherwise or in a different way. Mental illness can bring about a need to hide or to protect one's thoughts from others. One can cover his/ her ideas by using symbols and symbol combinations associated with non-conventional meanings. However, the use of secret symbols can also be accompanied by the wish for someone to detect the intended message.

Among the drawings and paintings in the Nikkilä collection there are also some pictures of people praying. In one work depicting two adults and a child, the adult characters are placed standing with their backs towards each other whilst the praying child figure stands between them. The work gives an impression that the child is trying to act as a mediator between the adults, probably hoping to be able to build a connection between them. Furthermore, one picture depicts a young girl kneeling in prayer and another picture a male figure kneeling and praying beside a female figure with dark dress and white headdress. Praying can be seen as an attempt to create a connection outside oneself.

\section{Angels, devils and the Fall}

In addition to pictures of the Virgin Mary, Christ and praying people there are numerous angels in the Nikkilä collection. In one 
drawing, a traditional guardian angel is taking a child home, and in another work, a slightly melancholic angelic figure sits leaning on an anchor - a symbol of hope. The work evokes associations with the theme of melancholy in art, such as Albrecht Dürer's (1471-1528) work entitled Melencolia I (1514).

Sometimes there are also devils in the pictures alongside the angels. In his book A Social History of Madness (1987) Roy Porter describes the case of Christoph Haitzmann (1651/2-1700) who was a poor Bavarian-born Austrian painter famous for his autobiographical depictions of encounters with the devil. Through the study of Haitzmann Porter describes different, culturally and historically changing explanations for madness. When the anxiety caused by the devil has traditionally been understood as an important reason for madness, excessive religiosity has later also been seen as a cause of mental illness (Porter 1987: 82-9; Pietikäinen 2013: 23-56). As stated by Pietikäinen, between the world wars Finnish people were still very religious, particularly in rural areas of the country. In Finnish psychiatric hospitals there were numerous patients plagued by guilt and anguish and afraid of the

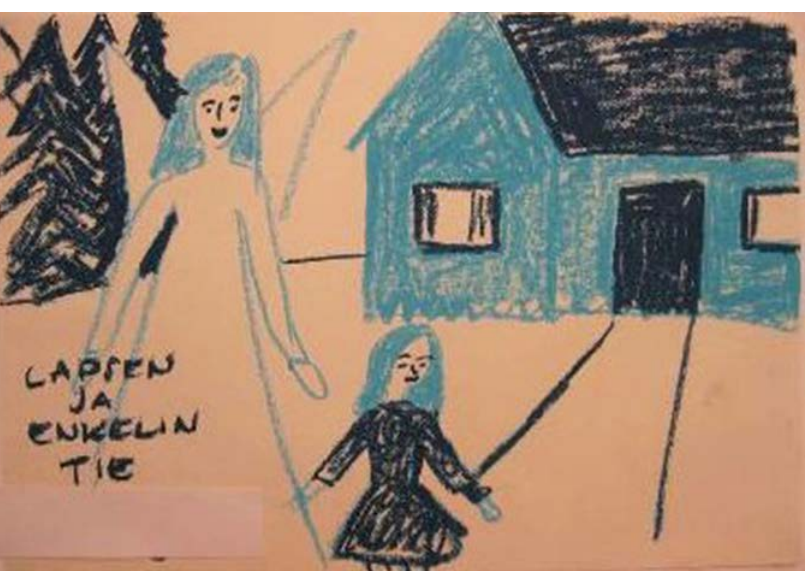

Helsinki City Museum, NSM - EiNo, 1986. Text in the picture: 'The way of the child and the angel'.

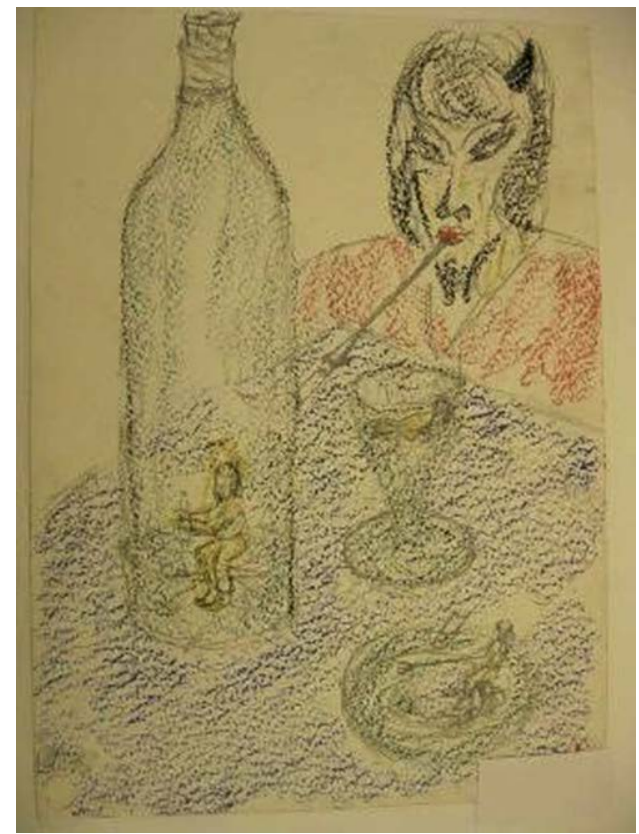

Helsinki City Museum, NSM I121 - 2813, no date.

devil and perdition. In cases like this religiousness was sometimes understood to be one cause of mental illness (Pietikäinen 2020: 145, 217).

In the pictures of the Nikkilä collection devils often have horns and a goatee beard. In one work, the devil figure is observing human beings living in a bottle and other vessels. Sometimes the figure of the devil is placed near the flames or is present in the pictures of the Last Judgment or the horrors of Hell. Some pictures seem to have connections with the imagery of Hieronymus Bosch (c.1450-1516). There are deformed figures in these pictures. The figures are sometimes partially fused into each other.

The theme of evil has connections with Christian ideas of original sin and the motif of the Fall. One work of the Nikkilä collection carries clear connections with the imagery of the Fall. In that work Adam and Eve are standing in the shadow of the apple tree, with a slithering snake around them. This work has been made co-operatively 


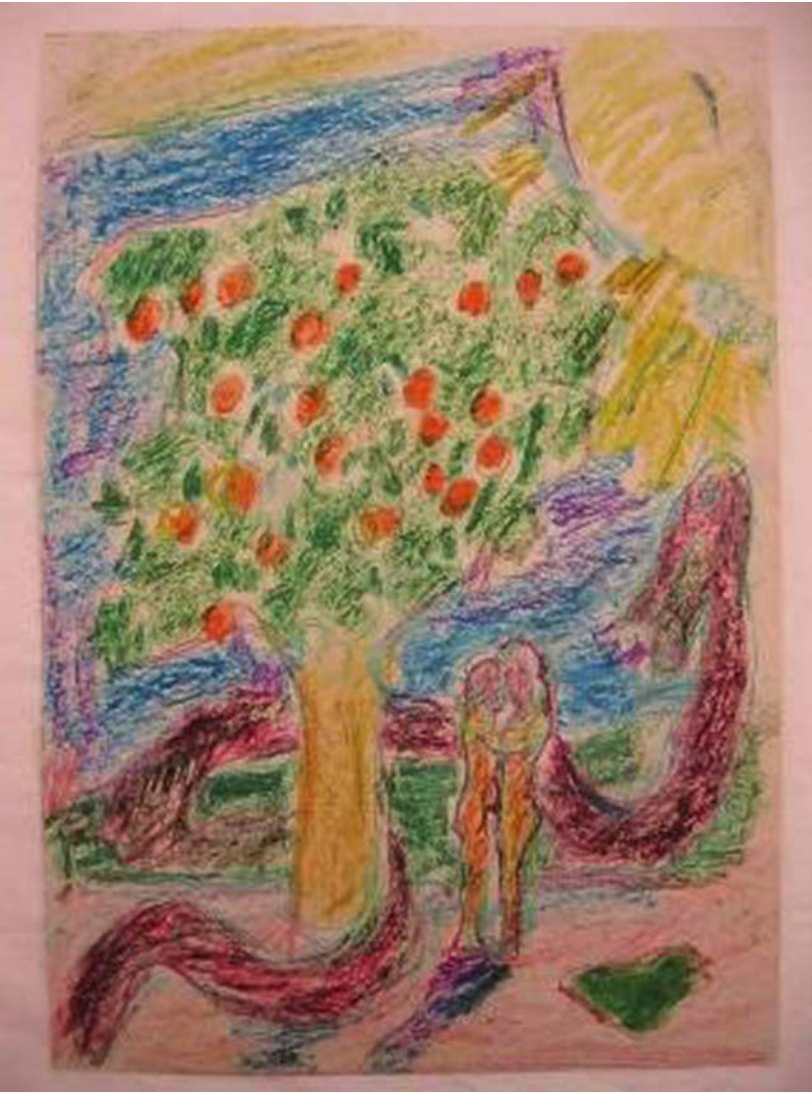

Helsinki City Museum, NSM 1121 - 3674, no date. Markings on the reverse side of the painting: 'Rafael Wardi and patient N. N. He/ she used art reproductions in his/her drawings or the works of other clubmates which he/she then treated in her own way.'

with a Nikkilä patient and the artist Wardi. In addition to the giant figure of the snake there are also other mythic creatures to be found in the collection, such as a dragon, a winged horse, and a winged snake.

In the Nikkilä collection there is also one picture of the apostles Matthew, Mark, Luke and John who are symbolically depicted as a human figure, a lion, an ox, and an eagle. Biblical themes are also present in the picture where a human figure, called Judas in the caption, is hanging from a tree. On the background of the picture there are crosses and probably a cemetery. ${ }^{2}$

\section{The cross}

The cross is a frequently-repeated symbol in the works of the Nikkilä collection. The simplest version of the cross motif is a small black cross in the middle of an otherwise blank piece of white paper.

As described by Wardi, even drawing a few lines would sometimes provide release for the patients:

I thought that by going among those patients, by being with them I would stand by them. The little I could do was try to teach them to find themselves, to be themselves. We can all be some kind of prisoner; prisoners of our work, prisoners of the family, prisoners of our illness. Art can be a release, even if one draws a few lines. (Wardi in Anhava 2005: 104, trans. Sari Kuuva) ${ }^{3}$

2 In some cases the texts referring to religious themes have been attached to the pictures. For example, the words 'The Lord Jesus, my A and O' ('Herren Jesus mitt A ja O') are present in the work depicting flowers and ears of grain. The nuclear missile and the swamp-like dark cloud depicted in one work, are accompanied by the words 'For behold, that day is burning like a loaf. Malachi 4' ('Sillä katso se päivä on palava kuin pätsi. Malakia 4']. One picture is adorned with the text 'Jesus or something in that direction' ('Jeesus tai jotain siihen suuntaan') and the other contains the words 'Home, religion and homeland' ('Koti, uskonto ja isänmaa'). What is probably a critical statement on the doctrine of the trinity of Christianity can be seen in an arrangement of two overlapping triangular patterns with the words 'This is how people are made to be' ('Näin asetetaan ihmisiä olemaan'). In the work entitled as Nunnatarhat - Gardens of Nun, the human figure is placed inside a labyrinth with a circular pattern. These constellations are prehistoric stone structures found in Finland.

3 'Ajattelin että menemällä niiden potilaiden joukkoon, olemalla heidän kanssaan 


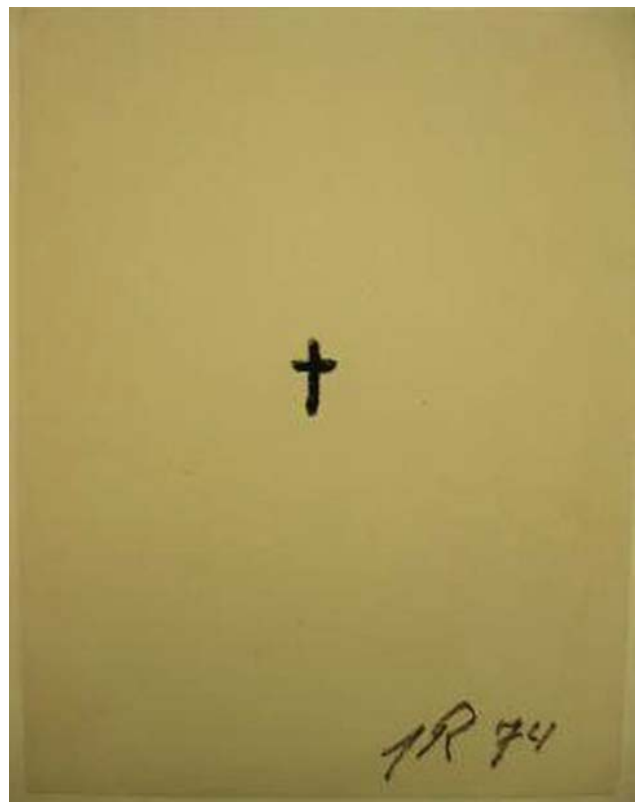

Helsinki City Museum, NSM I121 - 1358, 1974.

Sometimes the cross appears as part of an abstract composition in the pictures, as an ornamental pattern without clear reference to any religious meaning. At times, the cross pattern has been used in the works quite conventionally; for example in a combination of signs referring to faith, hope and love - the cross, anchor and heart. Sometimes the cross pattern is incorporated into the clothing of the persons depicted, such as caregivers or people wearing insignia. When human figures have been described as having a pendant cross around their neck, this can probably be read as a reference to their religiousness.

The cross pattern is sometimes also included in rather enigmatic compositions.

asetun heidän puolelleen. Se vähä mitä saatoin tehdä oli sitä että yritin opettaa heidät löytämään itsensä, olemaan oma itsensä. Kaikki me voimme olla jonkinlaisia vankeja. Työmme vankeja, perheen vankeja, sairautemme vankeja. Taide voi vapauttaa, jo se että vetää muutaman viivan' (Wardi in Anhava 2005: 104).
In one picture, a punk-haired girl is depicted leaning disconsolately on a cross, with fallen crosses in the background. In another work, a cross is placed on top of a stone jar, and next to it is a bleeding hand with long red nails. The work could refer, for example, to feminine pain and suffering, by moving the symbols of Christianity into a new context. In Prinzhorn's study also, feminine suffering has been depicted in a picture where the crucified figure is a woman (Prinzhorn 1922/72: 90-3).

\section{Churches, liturgical colours and light}

Sometimes cross shapes can also be seen in the windows of buildings and rooms depicted in the pictures. There are also many works of church buildings and bell towers in the Nikkilä collection. This is probably partly due to the fact that churches have been very dominant elements in the landscapes of Finnish villages and towns. Traditionally, some Finnish people have had a picture of their own church in a significant place in their home. In some works of the patients, the church is the main motif and at other times it is part of a wider landscape. There are wooden churches in the Nikkilä collection, as well as stone churches, churches of small rural localities and nationally recognizable buildings, such as Porvoo Church and Helsinki Cathedral. Usually, exteriors of the churches have been depicted, but individual patients have also depicted their interiors, such as the altar. Sometimes the Finnish flag fluttering in the churchyard, or the closed gate of the church appear to be significant details of the pictures.

Colour theorists, such as Johann Wolfgang von Goethe (1749-1832) and Wassily Kandinsky (1866-1944), have widely described the spiritual aspects of colours (e.g. Goethe 1810/2019; Kandinsky 1911/77). In the patients' works, it is 


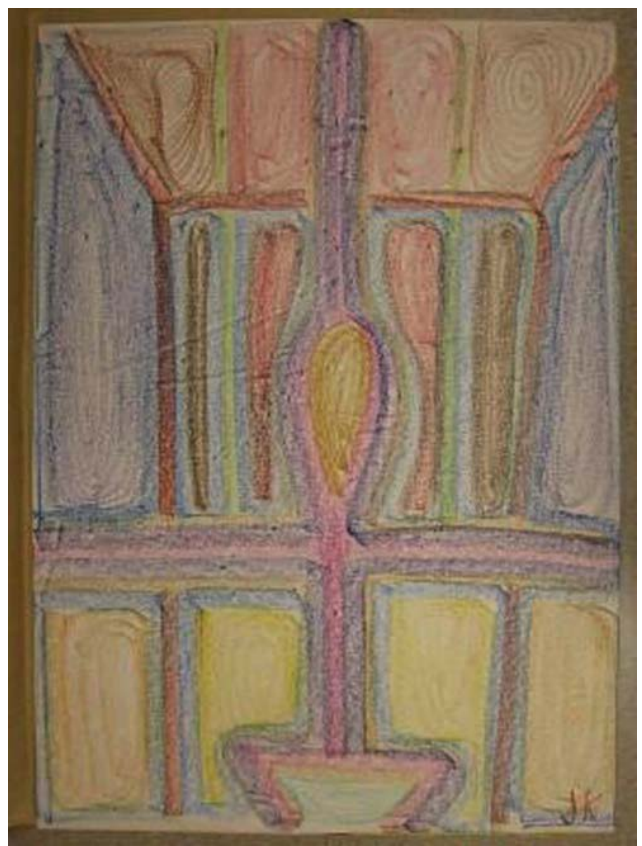

Helsinki City Museum, NSM 1121 - EiNo, no date.

sometimes difficult to evaluate how conscious the use of colours and other symbols has been; in other words, how aware the authors have been of the conventional meanings of the symbolism they have utilized, and how consciously they have wanted to attach new, personal meanings to the symbols. In the series of crayon drawings which arouse associations with the stained glass windows of the churches, the combinations of forms and colours carry close connections with the conventions of ecclesiastical art. The works contain liturgical colours such as blue, purple, and red, as well as yellow - probably as a reference to light. The works can be compared, for example, with Edwin Lydén's (1879-1956) work entitled Sunday (Söndag, Sunnuntai), whose abstract forms and colours and light impression evoke impressions of sacral space.

Wardi, the instructor of the Nikkilä Hospital Art Club, is known for his colourful works. According to Wardi colours do not represent something thoroughly defined, as any colour changes when another colour appears alongside it. Therefore, for him colour is a relationship, not a thing in itself (Wardi in Anhava 2009: 52). The artist also sees the relationship between light and darkness as relational and has stated 'The harder the light, the deeper the darkness. I thought I invented it myself until I realized it was already in the Bible' (Wardi in Anhava 2005: 60). Wardi's own religious roots are in Judaism, but he has stayed open to spiritualities different from his own religion. As the artist has mentioned in interview, his own Judaism has probably opened his eyes to the position of discriminated people such as psychiatric patients (Tikka and Tukia forthcoming).

\section{Boats and ships}

Sometimes the symbol of the cross can also be observed in the pictures of sailing ships with cross-shaped masts. Various boats and ships are frequently repeating motifs in the Nikkilä collection. However, not all pictures of ships and boats are likely to be religious; there are also landscapes where they are more like elements of the landscape. However, boats and ships have been important spiritual and religious symbols, from the crossing of the Tuonela River to Noah's Ark. They have alluded to travel, the journey of life, and the transition to the afterlife, and life itself has been compared to a stormy sea in many contexts (see, e.g. Biedermann 1996: 184). Ships and boats can be driven by winds, at the mercy of external conditions. Fluctuations between storm and calm and surprising pitfalls may also be important in the boat and ship symbolism of the Nikkilä collection. The Norwegian artist Edvard Munch (1863-1944), who suffered from mood swings, also described his life and illness by means of ship comparisons (e.g. Stang 1980: 15, 24). 
Wardi has said that one patient tended to paint the seascape again and again and in all of his pictures there was a black ship. When the patient was asked why he always painted the same motif, he replied that it was his motif and explained that some light was still missing from the picture (Wardi in Tuovinen 2009: 189). In the Nikkilä collection the changing seasons and moments of the day also bring a variety of effects to bodies of water. The works depict very different kinds of ships, from rowing boats to sailboats, cargo and passenger ships, even submarines, sailing both in Finnish landscapes and in distant lands. Rowing boats are often features of the landscape in the pictures, when the ships are usually the main motifs of works and the pictures of ships do not usually include human figures. Sometimes the ships are shipwrecked, sinking or burning.

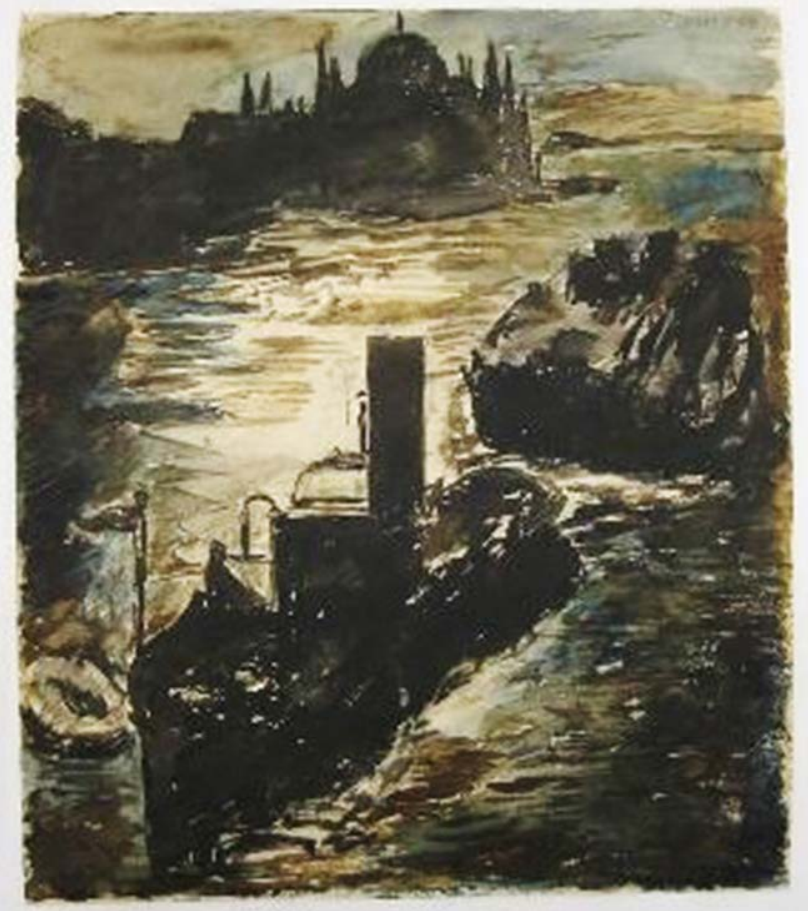

Helsinki City Museum, NSM I121 - 844, no date.

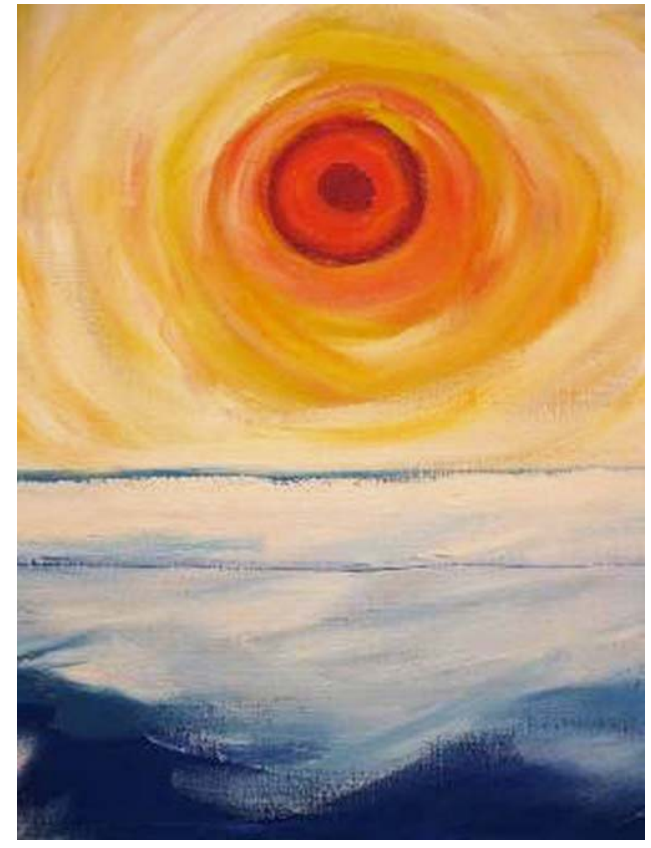

Helsinki City Museum, NSM 1121 - EiNo, 1982 ? Text in the wrapping paper of the work: 'Sunset'.

An essential point in patients' pictures of ships and boats is probably their connection with a voyage that is conceivable as a kind of liminal state, as the period of hospitalization can be for some patients (cf. e.g. Heimonen and Kuuva 2020: 344). In Finland, the ship is also intertwined with the thematics of psychiatric hospitals in association with the island of Seili, where the patients, often diagnosed as incurable, were placed from the late seventeenth century until the 196os. In the context of ship symbolism in the pictures of the patients, it is also essential to remember the allegory inherited from Plato's Republic (c.375 BC) - the Ship of the Mad - which has since been dealt with by numerous visual artists, such as Albrecht Dürer (1471-1528) and Hieronymus Bosch.

\section{Spiritual landscapes}

In addition to symbols relating to manmade buildings and objects, there is also 
plenty of natural symbolism in the pictures of the Nikkilä collection, such as trees, flowers, bodies of water and mountain landscapes during different seasons. Sometimes natural forms or phenomena such as sunshine, moonlight, planets, constellations of stars, rainbows, or storms, are so powerfully visualized that the expression makes the viewer reflect on the spiritual meanings of the work. Some works containing the symbols of nature have interesting connections to the art of Romanticism and Symbolism in which, for example, lofty mountains and water, moonlit nights, intense sunbeams and fog-blurred landscapes have been central (e.g. Brodskaia 2007: 18, 40-1, 46, 92 ).

In one work of the Nikkilä collection, couples are standing on a beach in the shade of some trees observing a special phenomenon of light, possibly a sunset, dominated by tones of red and orange. A lone figure in a robe has turned his/her back towards the crowd. Characters shrouded in robes and cloaks have been frequently depicted in the esoteric art of the turn of the nineteenth and twentieth centuries, and this kind of clothing was often associated with consecrated masters and those seeking their hidden wisdom. For example, the cloaks and robes of priests, monks, saints and philosophers have referred to their higher, spiritual knowledge. Finnish artists such as Akseli Gallen-Kallela (18651931) and Pekka Halonen (1865-1933), among others, depicted truth-seekers reaching towards secret information often clothed in robes or cloaks (Kokkinen 202ob: 13). When looking closely at the clothing of the human figures described in the works of the Nikkilä collection, it is possible to notice that people's robed outfits tend to root them in the ground, so that people's bodies resemble tree trunks. The motif has somehow a similar spirituality to that of the

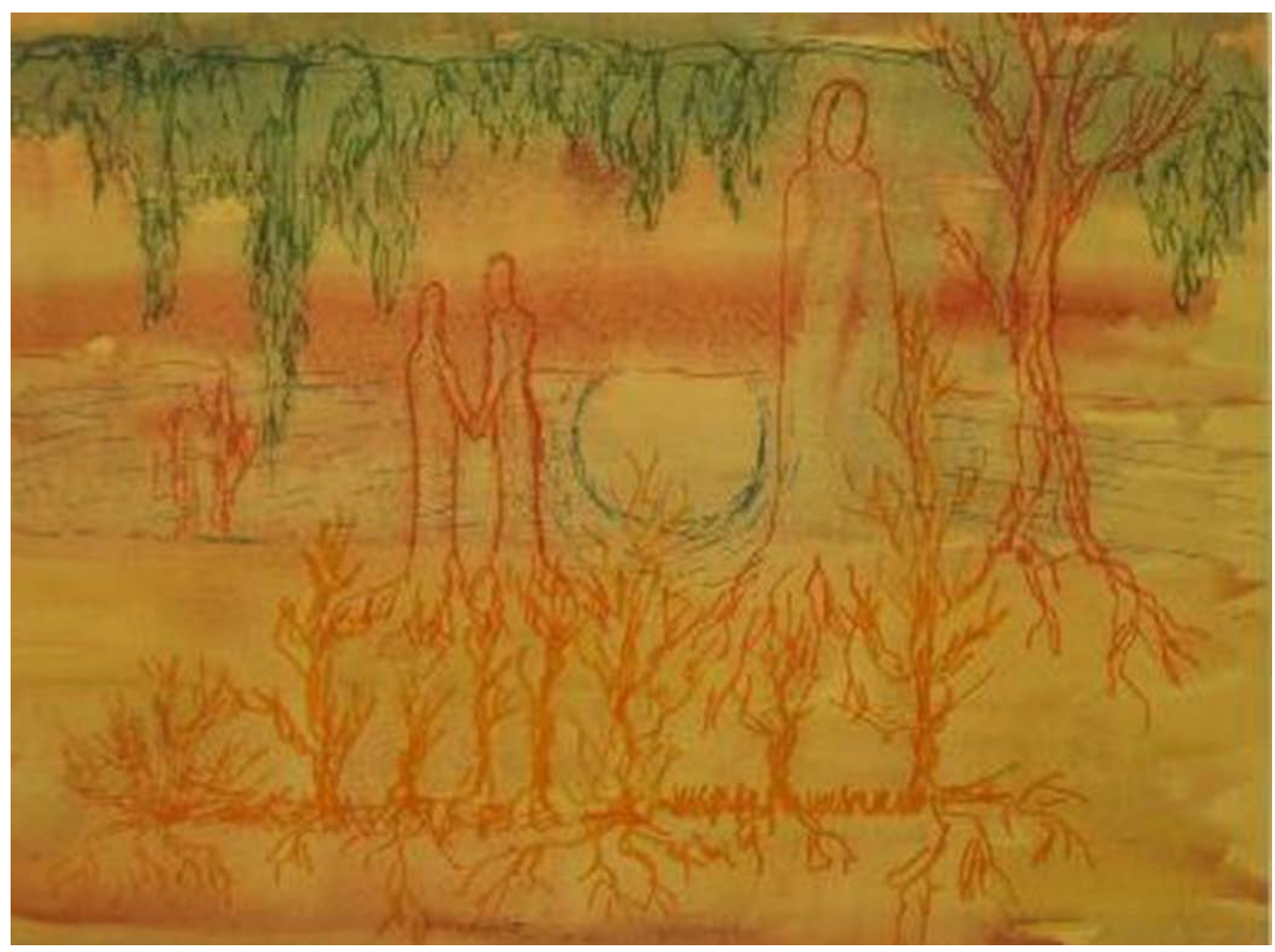

Helsinki City Museum, NSM I121 - 1431, no date. 


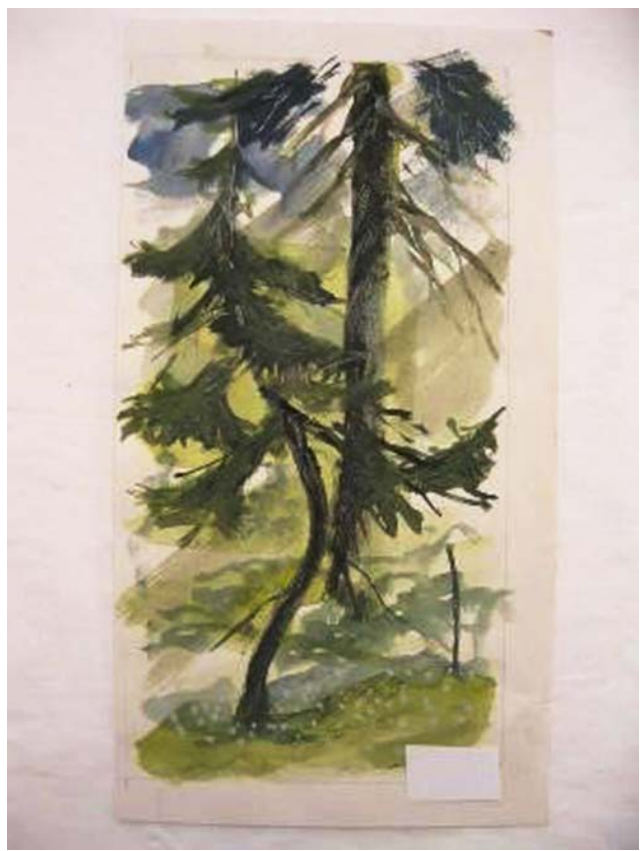

Helsinki City Museum, NSM I121 - 2053, 1977.

Symbolist art of the turn of the nineteenth and twentieth centuries. The work arouses associations, for example, with many of Edvard Munch's pictures in which people standing on a beach are juxtaposed with trees (see, e.g. Brodskaia 2007: 30; Kuuva 2010: 85-9).

In the Nikkilä collection there are also numerous works which seem to suggest that natural symbols such as trees and plants are used as symbols for the author's own situation and also reflect his/her experience of the surrounding reality, including spiritual and religious experiences. In his studies of alchemy Carl Gustav Jung (1875-1961) frequently discussed the symbolism of the tree and analysed the pictures containing the tree motif produced by his patients. As stated by Jung, the tree is an image which frequently appears among archetypal configurations of the unconscious and in tree motifs the self is usually depicted as being in a process of growth. Of course, the religious symbolism of the Tree of Life is also an essential feature in the context of tree motifs (Jung 1967/78: 253, 272; Kuuva 2010: 137-43).

Sometimes the relationship between man and nature has also been approached through flower symbolism. For example, in a work entitled Underwater Flower Girl (Vedenalainen kukkaistyttö) the human body represented seems to grow flowers. The mode of description has connections, for example, with the ways in which Symbolist writers and artists treated the cycle of life and death. It was thought that dead matter serves as a breeding ground for new life - for flowers, trees, and the human beings (e.g. Tøjner 2000: 92; Kuuva 2010: 141-3). The symbolism of nature has been closely linked with spirituality in Finland and other Nordic countries, both in the context of Symbolist art and more recently in the New Age cultures (e.g. Kokkinen 2019a, 2019b; Thurfiell 2020).

\section{Esoteric spirituality}

In addition to Christian symbolism, symbolism of other religions can also be observed in the individual pictures. For example, some works depict minarets and god figures with the features of Indian religious figures with their typical attributes, such as numerous hands with conventional postures, mudras, stylized facial features, and rich jewellery. One work interestingly combines the conventions of the Christian motif of the Virgin Mary and child with the conventions of Indian religious pictures. The visual expression of the work has connections, for example, with the works of Ilona Harima (1911-86) (see, e.g. Kokkinen 2020a: 91-9).

The Nikkilä collection also contains works that utilize the symbols of death, such as skulls, skeletal figures and a coffin. One artist has depicted a death mask. She has also utilized religious symbolism in other 


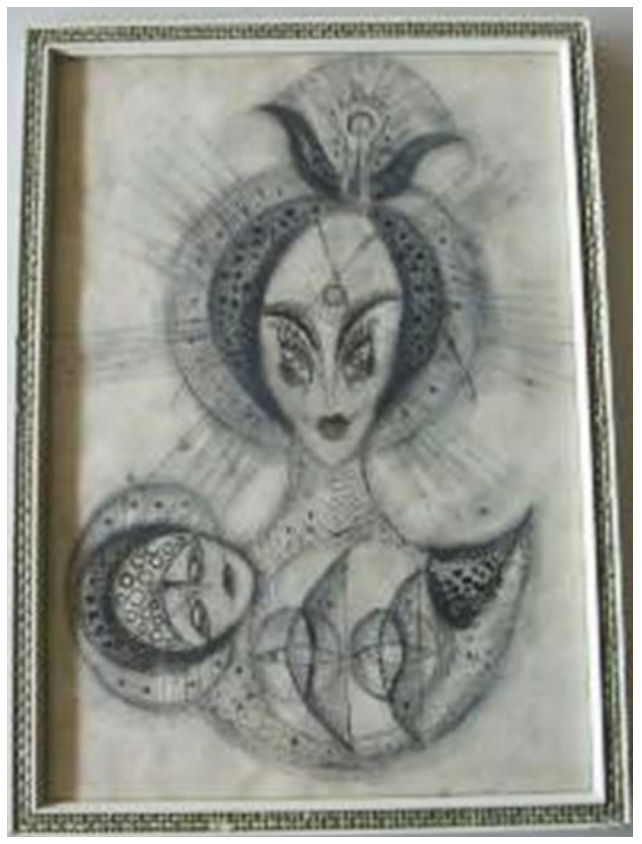

Helsinki City Museum, NSM I121 - 3554, 1978.

ways in the context of her self-portraits. She has described herself, for example, as a saint, with a halo above her head, with a crown of thorns, with a cross around neck, and in the clothes of a nun. She has also made a work entitled Wireless Electricity: An Animated Electricity (Langaton sähkö animaalinen sähkö) in which red wires pass between people. ${ }^{4}$

Towards the end of the nineteenth century, new phenomena such as electricity and magnetism were investigated and used to develop new technology. For example, an electronic telegraph enabling communication over long distances was developed. At the turn of the twentieth century, however, the new phenomena were not yet

4 Interestingly, the red wire between people has also been essential symbol in Michelle Williams Gamaker's performance entitled 'The effectiveness of symbols: psychogeographic explorations of the body' where the artist deals with the relationship between corporeality and mental suffering (Williams Gamaker 2020: 282-95). fully understood and they also became the subject of esoteric reflection. In this context the possibilities for communication with the hereafter captured the imagination of the artists (von Boguslawski 2020: 204). For example, Edvard Munch reflected in his notes on the subject of wireless communication, stating that he sought to depict this theme in his pictures by means of wavy lines crossing through and between people (e.g. Tøjner 2000: 110). As the author and doctor Laura Latvala (1921-86), who worked in a psychiatric hospital, described in her book Tuulien talo (1964), the contents of the delusions of the patients tend to change over time (Latvala 1964: 94). Also, Tanya Luhrmann and her research team have shown cultural differences between the delusions experienced by patients (e.g. Luhrmann et al. 2014: 1-18).

Among the works of the Nikkilä collection there were only individual pictures which clearly seemed esoteric to me. In these works connections with esoteric ideas from the turn of the twentieth century could be observed and there were also combinations of Western and Eastern religious symbolism with ideas of wireless communication. In addition to these few works there were other works in the context of which I could not be sure how intentional the symbolism of the works was, or whether there was some message for the beholder or not. Sometimes the intentions behind the works were clarified through the texts linked with the pictures, such as in the context of the work containing the text 'Wireless electricity' ('langaton sähkö).

\section{Conclusion}

As seen in this article, among the religious and spiritual motifs of the Nikkilä collection there are pictures of both consolation and anxiety, and traditional ecclesiastical 


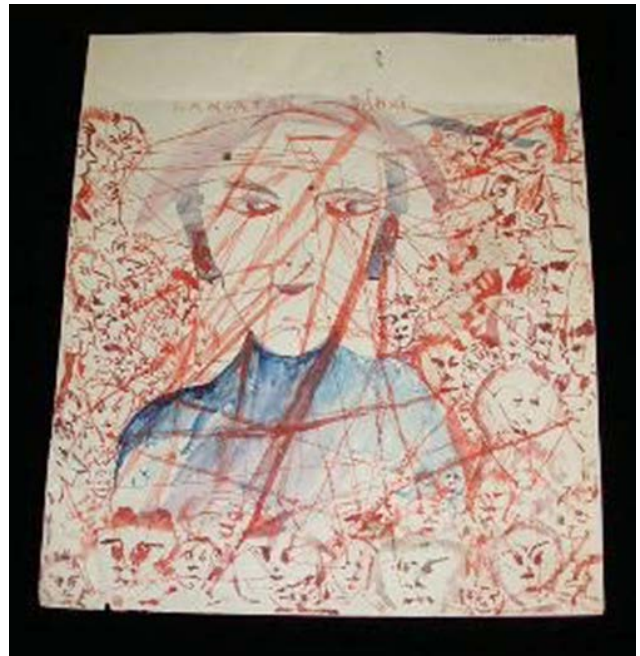

Helsinki City Museum, NSM I121 - 3381, 1940s. Text in the picture: 'Wireless electricity'.

art has greatly influenced on the imagery used by the patients. There are also clear connections between religious motifs in the Nikkilä collection and the art of psychiatric patients internationally (cf. e.g. Prinzhorn 1922/72; MacGregor 1989).

The pictures which I have interpreted as religious or spiritual form a fairly large portion of the Nikkilä collection. With a total of about 2,00o digitized works, there were about 200 pictures in the context of which I have reflected on their religiousness and spirituality. The works, such as pictures of Christ, the Virgin Mary, angels and devils, are based on the stories of the Bible and Christian iconography, and they can clearly be understood as religious. However, in the context of spiritual works the situation is already more complex and open to various interpretations. For example, which kinds of landscapes or abstract compositions are spiritual and which are not? In the Nikkilä collection most of the pictures which I have interpreted as spiritual contain symbolism of nature. While reflecting on the spirituality in the context of the Nikkilä collection I have often compared the works of the patients with works known from the history of art - thus assuming that the works of the patients may contain the same kind of spirituality as, for example, the works of Romantic and Symbolist artists.

During the process of study I have continuously reflected what we can really infer about the religious and spiritual experiences of the artists on the basis of their works. It is possible that making a picture is a devotional activity and that pictures have been made, for example, to function as instruments in religious rituals for the patients. Working with religious and spiritual themes through visual symbols can be positive experience if the motif is in harmony with one's own values and identity. On the other hand, it is possible that making art in itself is a process that promotes well-being by freeing the patient from the everyday life of the psychiatric hospital for a moment and by making his/her own handprint visible - whatever the motif.

During the research process I have also wondered how the patients have chosen the famous works from the history of art that they have decided to copy. Are the topics the ones for which a model has easily been found, for example, from a print in the patient's possession, or from the library of Nikkilä Hospital? Books of art history were available in the library at Nikkilä Hospital, and they were eagerly read. As a former librarian there has said, the Bible, and the Old Testament in particular, was the most frequently loaned book in Nikkilä. It has also been stated that the patients tended to read philosophical books when they were in better condition and theological books when they felt worse (Tuovinen 2009: 85).

Can theological literature give clearer answers and guidance to suffering people than philosophical texts? For example, the motif of the suffering Christ can be comforting for some patients as it brings an object of identification with one's own pain 
and anguish, and also the related idea of atonement can bring hope to one's own situation. Interpretations in which Christ is depicted wearing his crown of thorns or carrying his cross are popular motifs in the pictures of the Nikkilä collection. In addition to the figure of Christ, the Virgin Mary also appears quite often in these works, as in the international context of the art of psychiatric patients. Unfortunately, it is not possible to ascertain through study of the digitized material and the information included with the pictures whether there are some gendered differences in the choices of motifs in the Nikkilä collection.

Because many of the clearly religious subjects are copies of existing works, they reproduce Christian iconography very faithfully. In individual works, however, an unconventional combination of Western and Oriental forms of expression can be observed. In these pictures it is possible to see reflections of the esoteric ideas where the threads of different religions have been combined. Patients' works were made by both professional artists in psychiatric care and those who did not have any artistic training. Both groups probably made pictures on the basis of their own starting points and needs.

The making of the pictures was probably influenced by previous experiences of art and life, including the situation for artistic work in the hospital environment, other attendees of the art club, instructions for the work, as well as the available materials and possible models for the pictures. Particularly in the early twentieth century, the equipment needed for artistic work in psychiatric hospitals was quite scarce. Patients have probably used paper and other materials quite sparingly. For example, drawings have sometimes been made on both sides of the paper. This phenomenon is also known internationally and some patient artists have used unusual materials in their works. For example, one of the artists in Prinzhorn's art collection made sculptures out of the bread he was chewing (Prinzhorn 1922/72: 106).

The Nikkilä collection displays many connections with international collections of the works of the patients of psychiatric hospitals. In international collections religious motifs have also been central. However, I was surprised that there was a relatively low number of highly enigmatic works among the pictures of Nikkilä. I wonder whether it is a question of Finnish patients not making these types of pictures, or that it has not been decided to store these pictures in the collection of the hospital museum. In international study of the art of the patients of psychiatric hospitals, more cryptic works have been frequently presented. Based on the digitized material of the Nikkilä collection, it seems that the religious imagery of Finnish patients is more restrained and conventional than the art of the patients in many other collections internationally. An extreme example of the use of religious imagery in the art of the patients of psychiatric hospitals can be found in the production of a Swiss patient, Adolf Wölfli (1864-1930) (e.g. MacGregor 1989: 206-21).

The nature of the patients' works is likely to be affected, for example, by the kind of pictures and stories they already knew. When comparing, for example, the Catholic imagery of southern Europe with the pictures in Finnish Protestant churches, the differences are evident. Colourful stories of saints and their illustrations have not been as dominantly present in Finnish Lutheran churches as in Catholic churches of southern Europe. Therefore, this type of imagery has not fed the pictorial imagination of Finnish patients to the same extent as in southern Europe. 
Pictures that appear spiritual rather than clearly religious often have connections with, for example, the imagery and forms of expression of Romantic and Symbolist art. In addition, some of the works have a clear tendency to abstract expression, for which various points of comparison can be found in Finnish art of the twentieth century. Both Romantic and Symbolist art have been well represented in Finnish art collections, for example in the Sinebrychoff collection and at the Ateneum, and some patients have probably been quite familiar with artistic traditions and contemporary art displayed in Helsinki.

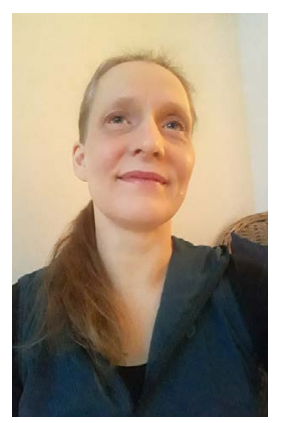

PhD Sari Kuuva's (art history, 2010 and cognitive science, 2007) investigations have focused on the relationship between art, visual culture and the mind. Her dissertation of art history Symbol, Munch and Creativity: Metabolism of Visual Symbols (2010) focused on the concept of symbol. Kuuva has also studied the use of symbols in the context of religious processions. In recent years, she has worked in the multidisciplinary research project 'Engraved in the Body: Ways of Reading Finnish People's Memories of Mental Hospitals' (Kone Foundation, 2017-20) by studying emotional experiences and embodied knowledge relating to psychiatric institutions. She has published widely on the topic of mental illness and psychiatric hospitals. In 2020-1, Kuuva has studied the art of the patients in Finnish psychiatric hospital museums and collections with the support of funding from the Finnish Cultural Foundation and Ella and Georg Ehrnrooth Foundation.

\section{List of references}

\section{Unpublished references}

Kallio, Elina (Chief Curator, Helsinki City Museum), e-mail to Sari Kuuva 2.5.2019.

\section{Published references}

Achté, Kalle. 1982. 'Esipuhe', in K. J. Lind: Erään sielunpaimenen muistiinpanot koskien mielisairaita ja heidän hoitoaan, vols. 1-5, trans. Kristina Labart (Helsinki: Helsingin yliopistollinen keskussairaala), 1-4.

Anhava, Martti. 2005. Rafael Wardi ja värin ilo (Helsinki: WSOY).

Beyme, Ingrid von, et al. (eds.). 2019. Gewächse der Seele. Pflanzen-fantasien zwischen Symbolismus und Outsider Art. Floral Fantasies between Symbolism and Outsider Art (Berlin: Hatje Cantz).

Biedermann, Hans. 1996. Suuri symbolikirja [orig. Knaurs Lexikon der Symbole, 1989], trans. and ed., Pentti Lempiäinen (Porvoo, Helsinki, Juva: WSOY).

Boguslawski, Julia von. 2020. 'Esoterian suhde tieteeseen', in Moderni esoteerisuus ja okkultismi Suomessa, eds. Tiina Mahlamäki and Niina Kokkinen (Tampere: Vastapaino), 195-220.

Brodskaia, Nathalia. 2007. Symbolism (Kent: Grange Books).

Cadogan, Jukka. 2008. 'Mielisairaiden taide Suomessa. Tutkielma psyykkisesti sairaiden taiteen vastaanotosta taidekentällä ja julkisuudessa 1915-1971', master's thesis (University of Helsinki).

Elovirta, Arja. 2005. Omissa maailmoissa. Taidetta, terapiaa ja liiteripicassoja (Helsinki: Maahenki).

Goethe, Johann Wolfgang von. 1810/2019. Värioppi [orig. Zur Farbenlehre, 1810], trans. Pirkko Holmberg and Pajari Räsänen (Helsinki: Taide).

Hämäläinen, Helena. (Forthcoming). 'Potilaiden kädenjälkiä. Potilastaide ja potilastyöt terveysalan kokoelmissa, in Terveys tallessa. Sata kokoelmaa ja museota Uudeltamaalta, eds. Henna Sinisalo, Maria Tukia, Helena Hämäläinen and Anders Manns (Helsinki: HUSin museotoimikunta).

Hämäläinen, Tommi. 2018. 'Mielen kuva-arkistossa. Tutkielma oppimiskokemuksesta Nikkilän sairaalan potilastöiden äärellä, master's thesis (Helsinki: Aalto University). 
Hanegraaff, Wouter J. 2006. Dictionary of Gnosis \& Western Esotericism (Leiden, Boston: Brill).

Haveri, Minna. 2010. Nykykansantaide (Helsinki: Maahenki).

Heimonen, Kirsi, and Sari Kuuva. 2020. 'A corridor that moves: corporeal encounters with materiality in a mental hospital', in Material Cultures of Psychiatry, eds. Monika Ankele and Benoît Majerus (Bielefeld: Transcript), 334-53.

Jäntti, Saara, Kirsi Heimonen, Sari Kuuva, and Annastiina Mäkilä (eds.). 2019. Hulluus ja kulttuurinen mielenterveystutkimus (Jyväskylä: Jyväskylän yliopisto, Nykykulttuuri).

Jung, Carl Gustav. 1967/78. The Collected Works of C. G. Jung. Vol. 13: Alchemical Studies, trans. R. F. C. Hull (London, Henley: Routledge \& Kegan Paul).

Kandinsky, Wassily. 1911/77. Concerning the Spiritual in Art [orig. Über das Geistige in der Kunst, 1911], trans. M. T. H. Sadler (New York: Dover).

Kinnunen, Anna. 2020. Johtolankoja hulluuteen. Tutkimus mielen sairastamiseen kytkeytyvistä kulttuurisista käsityksistä, Kultaneito, 20 (Joensuu: Suomen kansantietouden tutkijain seura).

Kivivuori, Janne. 1999. Psykokirkko. Psykokulttuuri, uskonto ja moderni yhteiskunta (Helsinki: Gaudeamus).

Kokkinen, Nina. 2019a. Totuudenetsijät. Esoteerinen henkisyys Akseli Gallen-Kallelan, Pekka Halosen ja Hugo Simbergin taiteessa (Tampere: Vastapaino).

- -2019b. Totuudenetsijät. Vuosisadanvaihteen okkulttuuri ja moderni henkisyys Akseli Gallen-Kallelan, Pekka Halosen ja Hugo Simbergin taiteessa, $\mathrm{PhD}$ dissertation, Annales Universitatis Turkuensis, C 469 (University of Turku).

- - 2020a. 'Ilona Harima ja mediaalinen taide', in Hengen aarteet. Esoteerisuus Suomen taidemaailmassa 1890-1950, eds. Nina Kokkinen and Lotta Nylund (Helsinki: Parvs), 93-9.

- - 2020b. 'Initiaatio taiteen ja esoteerisuuden risteyksessä, in Hengen aarteet. Esoteerisuus Suomen taidemaailmassa 1890-1950, eds. Nina Kokkinen and Lotta Nylund (Helsinki: Parvs), 8-23.

Kokkinen, Nina, and Lotta Nylund (eds.). 2020. Hengen aarteet. Esoteerisuus Suomen taidemaailmassa 1890-1950 (Helsinki: Parvs).

Kuuva, Sari. 2010. Symbol, Munch and Creativity: Metabolism of Visual Symbols, $\mathrm{PhD}$ dissertation (University of Jyväskylä).

Latvala, Laura. 1964. Tuulien talo. Sairaalapäiväkirja (Porvoo, Helsinki: WSOY).

Lind, K. J. 1982. Erään sielunpaimenen muistiimpanot koskien mielisairaita ja heidän hoitoaan [orig. Ur en själasörjares anteckningar l. angående sinnesjuka och deras vård, 1911], trans. Kristina Labart (Helsinki: Helsingin yliopistollinen keskussairaala).

Luhrmann, Tanya, R. Padmavati, Hema Tharoor, and Osei Awasi. 2014. 'Hearing voices in different cultures: a social kindling hypothesis', Topics in Cognitive Science, 7(4): 1-18.

MacGregor, John M. 1989. The Discovery of the Art of the Insane (Princeton University Press).

Mahlamäki, Tiina, and Nina Kokkinen (eds.). 2020. Moderni esoteerisuus ja okkultismi Suomessa (Tampere: Vastapaino).

Moberg, Marcus, Måns Broo, Janne Kontala, and Peter Nynäs. 2015. 'Contemporary discursive formations', in On the Outskirts of 'the Church', eds. Peter Nynäs, Ruth Illman and Tuomas Martikainen (Zürich: Lit Verlag), 56-72.

Morgan, David. 1998. Visual Piety: A History and Theory of Popular Religious Images (Berkeley, Los Angeles, London: University of California Press).

Parland, Oscar. 1991. Tieto ja eläytyminen. Esseitä ja muistelmia (Porvoo, Helsinki, Juva: WSOY).

Pietikäinen, Petteri. 2013. Hulluuden historia (Helsinki: Gaudeamus).

-—2020. Kipeät sielut. Hulluuden historia Suomessa (Helsinki: Gaudeamus).

Porter, Roy. 1987. A Social History of Madness. Stories of the Insane (London: Weidenfeld and Nicolson).

Prinzhorn, Hans. 1922/72. Artistry of the Mentally Ill: A Contribution to the Psychology and Psychopathology of Configuration [orig. Bildnerei der Geisteskranken, 1922] (New York: Springer-Verlag).

Rhodes, Collin. 2004. Toinen taide - luovat erot [orig. Outsider Art: Spontaneous Alternatives (London: Thames \& Hudson), 2000] (Helsinki: Maahenki).

Salmesvuori, Päivi. 2020. 'Kuvitellut taivaalliset 
todellisuudet. Horrossaarnaaja Helena Konttinen ja enkelit', in Kuvittelu ja uskonto. Taustoja, tulkintaa ja sovelluksia, eds. Aila Viholainen, Jaana Kouri and Tiina Mahlamäki (Helsinki: SKS), 171-98.

Stang, Ragna. 1980. Edvard Munch. Ihminen ja taiteilija [orig. Edvard Munch. Mennesket og kunstneren, 1977], trans. Mikko Kilpi (Porvoo, Helsinki, Juva: WSOY).

Takanen, Ringa. 2020. Laupeus ja inhimillisyys. Naisten ääni, affektiiviset elemuodot ja ikonografian murros suomalaisissa alttaritauluissa vuosina 1897-1920, $\mathrm{PhD}$ dissertation (Turku: Turun yliopisto).

Thurfjell, David. 2020. Granskogsfolk. Hur naturen blev svenskarnas religion (Stockholm: Norstedts).

Tikka, Katja, and Maria Tukia. (Forthcoming). 'Rafael Wardi - varhaisen kuvataideterapian lähettiläs', Terveys tallessa. Sata kokoelmaa ja museota Uudeltamaalta, eds. Henna Sinisalo, Maria Tukia, Helena Hämäläinen and Anders Manns (Helsinki: HUSin museotoimikunta).

Tøjner, Poul Erik. 2000. Munch. Med egne ord (Oslo: Forlaget Press).

Tolvanen, Marko. 2006. "Marko Tolvasen "Kohdunsisäisiä unelmia". Kysymys mielisairaiden taiteen estetiikasta, master's thesis (University of Helsinki).

Tuohela, Kirsi. 2015. 'Sielun ja mielen sairaus. Varhaiset psyykkisen sairastamisen omaelämäkerrat Suomessa, in Kipupisteissä. Sairaus, kulttuuri ja modernisoituva Suomi, eds. Jutta Ahlbeck et al. (Turku: Utukirjat), 195-232.

Tuovinen, Sirkka Liisa. 2009. Inhimillinen Nikkilä. Helsingin suuri mielisairaala Sipoossa 1914-1999 (Helsinki: Helsingin kaupungin terveyskeskus).

Tuovinen, Sirkka Liisa, and Jukka Aronsson. 2018. Suomen mielisairaalamuseot ja kokoelmat (Helsinki: HUS).

Viholainen, Aila, Jaana Kouri, and Tiina Mahlamäki (eds.). 2020. Kuvittelu ja uskonto. Taustoja, tulkintaa ja sovelluksia (Helsinki: SKS).

Williams Gamaker, Michelle. 2020. 'The effectiveness of symbols: psychogeographic explorations of the body', in Material Cultures of Psychiatry, eds. Monika Ankele and Benoît Majerus (Bielefeld: Transcript), 282-95. 